\title{
The Role of Ethylene and Pollination in Petal Senescence and Ovary Growth of Brodiaea
}

\author{
Susan S. Han', Abraham H. Halevy², and Michael S. Reid \\ Department of Environmental Horticulture, University of California, Davis, CA 95616 \\ Additional index words. stigma receptivity, Triteleia laxa
}

\begin{abstract}
Unpollinated brodiaea (Triteleia laxa Benth.; syn. Brodiaea laxa) flowers produced no measurable $\mathrm{C}_{2} \mathrm{H}_{4}$ during their entire lives. Treatment with $\mathrm{C}_{2} \mathrm{H}_{4}\left(0.03 \mu \mathrm{l} \cdot\right.$ liter $\left.{ }^{-1}\right)$ induced senescence of open flowers, completely inhibited opening of buds and petal growth, and promoted ovary growth. Silver thiosulfate had no effect on flowers kept in air but counteracted the effects of applied $\mathrm{C}$, $\mathrm{H}$. The effect of $\mathrm{C}_{2} \mathrm{H}_{4}$ on ovary growth seems to be indirect, via promotion of petal senescence and mobilization of the petal's metabolites to the ovary. Brodiaea flowers are protandrous; the stigma appears to be receptive (as judged by a pollination-induced burst of ethylene synthesis) only when the petals start to senesce. At this stage, papillae on the stigma surface elongated and separated.
\end{abstract}

Triteleia laxa is a cormous plant native to California that has gained popularity in recent years as a cut-flower crop. Very little is known about the postharvest physiology and handling of the flowers. Ethylene $\left(\mathrm{C}_{2} \mathrm{H}_{4}\right)$ is the major factor regulating the senescence of flowers, such as carnations (Nichols, 1968), petunias (Whitehead et al., 1984), and some orchids (Gob et al., 1985). These show a climacteric rise in $\mathrm{C}_{2} \mathrm{H}_{4}$ production after pollination or at the onset of senescence, and their senescence is accelerated by exposure to relatively low concentrations of $\mathrm{C}_{2} \mathrm{H}_{1}$. Other flowers are sensitive to $\mathrm{C}_{2} \mathrm{H}_{4}$, although they produce little $\mathrm{C}_{2} \mathrm{H}_{4}$ themselves. For example, roses normally produce low levels of $\mathrm{C}_{2} \mathrm{H}_{4}$, but concentrations of $\mathrm{C}_{2} \mathrm{H}_{4}$ as low as $20 \mu \mathrm{l} \cdot$ liter $^{-1}$ can cause aberrations in bud opening of certain cultivars (Reid et al., 1988). Other flowers, such as cyclamen, are neither sensitive "to nor produce $\mathrm{C}_{2} \mathrm{H}_{4}$. When pollinated, however, they show a climacteric peak of $\mathrm{C}_{2} \mathrm{H}_{4}$ evolution and become sensitive to $\mathrm{C}_{2} \mathrm{H}_{4}$ (Halevy et al., 1984). Other "nonclimacteric" flowers, including many geophytes, produce very low levels of $\mathrm{C}_{2} \mathrm{H}_{4}$ throughout their lives and are apparently unaffected by exposure to $\mathrm{C}_{2} \mathrm{H}_{4}$ (Halevy and Mayak, 1981).

Because $\mathrm{C}_{2} \mathrm{H}_{4}$ is important in regulating the senescence of many flowers, we have studied the role of $\mathrm{C}_{2} \mathrm{H}_{4}$ and pollination in the postharvest life of brodiaea flowers.

\section{Materials and Methods}

Plant material. Flowers of 'Queen Fabiola' brodiaea were grown outdoors in Davis, Calif., under natural conditions. Unless otherwise stated, inflorescences were harvested when the first flower in the inflorescence opened. To prevent the confounding "effects of growth of bacteria in vase solutions, which can cause premature flower wilting, all postharvest solutions contained $200 \mathrm{mg}$ 8-hydroxyquinoline citrate (HQC)/liter. In experiments using single flowers, flower buds showing color were collected from intact plants and opened and held in the laboratory $\left(21 \mathrm{C}, 12 \mathrm{hr} 15 \mu \mathrm{mol} \cdot \mathrm{s}^{-1} \cdot \mathrm{m}^{-2}\right.$ cool-white fluorescent light each day, $60 \% \mathrm{RH}$ ) in solutions containing $2 \%$ sucrose and $200 \mathrm{mg} \mathrm{HQC/liter.} \mathrm{Unless} \mathrm{otherwise} \mathrm{stated,} \mathrm{the} \mathrm{experiments}$

Received for publication 29 Dec. 1988. The cost of publishing this paper was defrayed in part by the payment of page charges. Under postal regulations, this paper therefore must be hereby marked advertisement solely to indicate this fact.

'Present address: Dept. of Plant and Soil Sciences, French Hall, University of Massachusetts, Amherst, MA 01003.

${ }^{2}$ Permanent address: Faculty of Agriculture, The Hebrew University of Jerusalem, Rehovot 76-100 Israel. used 10 replications of single inflorescences or flowers. Each experiment was repeated at least twice.

Determination of flower longevity. Flower longevity was determined with flowers held in $2 \%$ sucrose and $200 \mathrm{mg} \mathrm{HQC/}$ liter under the laboratory conditions stated above. The vase life of the entire inflorescence was considered terminated when the number of senescent flowers exceeded the number of open flowers.

Determination of petal expansion. The degree of petal expansion was determined by measuring the petal area of each flower with a leaf area meter before and immediately after the treatments. The degree of expansion is expressed as the percentage increase over the initial area.

Effect of ethylene, aminooxyacetic acid, and silver thiosulfate. Individual flowers with their bases in opening solution were exposed to a flowing stream of air or air containing various concentrations of $\mathrm{C}_{2} \mathrm{H}_{4}$. Entire inflorescences or individual flowers were treated with silver thiosulfate (STS) by immersing the base of the stem or pedicel in STS solutions prepared as described by Reid et al. (1980). Unless otherwise stated, $4 \mathrm{mM}$ STS was applied for $30 \mathrm{~min}$. After treatment, the bases were rinsed with water to remove the residual STS. In experiments examining the effects of inhibitors of $\mathrm{C}_{2} \mathrm{H}_{4}$ production on pollination responses, stigmas of individual flowers were pretreated with 2 $\mu \mathrm{l}$ of either $1 \mathrm{mM}$ aminooxyacetic acid (AOA) or $2 \mathrm{mM}$ STS $30 \mathrm{~min}$ before pollination.

Determination of ethylene production. Ethylene production of individual flowers was measured by placing them in $35-\mathrm{ml}$ glass vials, sealed with serum caps, for $1 \mathrm{hr}$. In experiments where the time course of $\mathrm{C}_{2} \mathrm{H}_{4}$ production was measured, the vials were ventilated with $\mathrm{C}_{2} \mathrm{H}_{4}$-free air every 1 or $2 \mathrm{hr}$. Threemilliliter aliquots of the air in the vials were withdrawn and the $\mathrm{C}_{2} \mathrm{H}_{4}$ content of the air was determined using a gas chromatography fitted with a photoionization detector (minimum detectable $\mathrm{C}_{2} \mathrm{H}_{4}, 1$ nl-liter ${ }^{-1}$ ).

Scanning electron microscopy. Fresh samples of stigmas were collected at various stages from anthesis to senescence. They were fixed with $2 \%$ glutaraldehyde in $0.1 \mathrm{M}$ phosphate buffer $(\mathrm{pH} 7)$, dehydrated by passing through an ethanol series, critical point-dried in $\mathrm{CO}_{2}$, and examined and photographed using an ISI DS130 scanning electron microscope (SEM) (International Scientific Instrument, Pleasanton, Calif.).

\section{Results}

Effects of exposure to ethylene and treatment with STS on the longevity of the flowers. The normal life of individual flowers 
was 5 to 6 days (Table 1). No detectable $\mathrm{C}_{2} \mathrm{H}_{4}$ was produced from nonpollinated flowers during their entire life span (Fig. 1). Open flowers exposed to $\mathrm{C}_{2} \mathrm{H}_{4}\left(10 \mu \mathrm{l} \cdot\right.$ liter $\left.{ }^{-1}\right)$ wilted within 1 day and $\mathrm{C}_{2} \mathrm{H}_{4}$-treated buds failed to open, an effect associated with inhibition of bud elongation and petal expansion. Pretreatment with STS $(0.5 \mu \mathrm{mol} / \mathrm{stem})$ counteracted these $\mathrm{C}_{2} \mathrm{H}_{4}$ effects.

When in florescences harvested with one open flower were exposed to $\mathrm{C}_{2} \mathrm{H}_{4}\left(1,5\right.$, or $10 \mu \mathrm{l} \cdot$ liter $\left.^{-1}\right)$ for 2 days, > $50 \%$ of the buds never opened, even if placed after treatment in a budopening solution containing $2 \%$ sucrose and $200 \mathrm{mg} 8-\mathrm{HQC} /$ liter (data not shown).

The sensitivity of the flowers to $\mathrm{C}_{2} \mathrm{H}_{4}$ was tested by placing individual open flowers and buds in containers ventilated with $0.03,0.1 ; 0.2,0.5$, or $1 \mu \mathrm{C}_{2} \mathrm{H}_{4} /$ liter. All open flowers exposed to $\mathrm{C}_{2} \mathrm{H}_{4}$ concentrations higher than $0.1 \mu \mathrm{l} \cdot$ liter ${ }^{-1}$ wilted within $10 \mathrm{hr}$ (data not shown). Treatment with $0.03 \mu \mathrm{l} \mathrm{C}_{2} \mathrm{H}_{4}$ liter reduced the vase life of the flowers to one-third that of the controls and prevented petal expansion, elongation, and opening of flowers buds (data not shown).

Effect of ethylene treatment and petal removal on ovary growth. The ovaries of brodiaea flowers grew mainly after anthesis, when the petals had reached their final size and the flowers had opened (Fig. 2 B and C). There was no ovary growth at all in young buds with growing petals (which reached anthesis on the last day of the experiment) (Fig. 2A); flowers harvested

Table 1. Effect of ethylene ( $1 \mu \mathrm{l} \cdot$ liter $\left.^{-1}\right)$ and silver thiosulfate (STS) on flowering characteristics of Triteleia laxa flowers. Individual flowers or buds were placed in $2 \%$ sucrose + HQC. Data are the means of 10 flowers.

\begin{tabular}{lcccc}
\hline \hline & \multicolumn{5}{c}{ Pretreatment } \\
\cline { 2 - 6 } & \multicolumn{3}{c}{ Water } \\
& \multicolumn{5}{c}{ Treatment } \\
\cline { 2 - 6 } Flowering characteristic & $\mathrm{Air}$ & $\mathrm{C}_{2} \mathrm{H}_{4}$ & Air & $\mathrm{C}_{2} \mathrm{H}_{4}$ \\
\hline $\begin{array}{l}\text { Flower longevity (days) } \\
\text { Bud elongation (\%, 2 days } \\
\text { after treatment) }\end{array}$ & 5.6 & 0.4 & 5.8 & 3.0 \\
$\begin{array}{c}\text { Petal expansion (percent } \\
\text { of initial area, 4 days } \\
\text { after treatment) }\end{array}$ & 58 & 17 & 67 & 67 \\
\hline
\end{tabular}

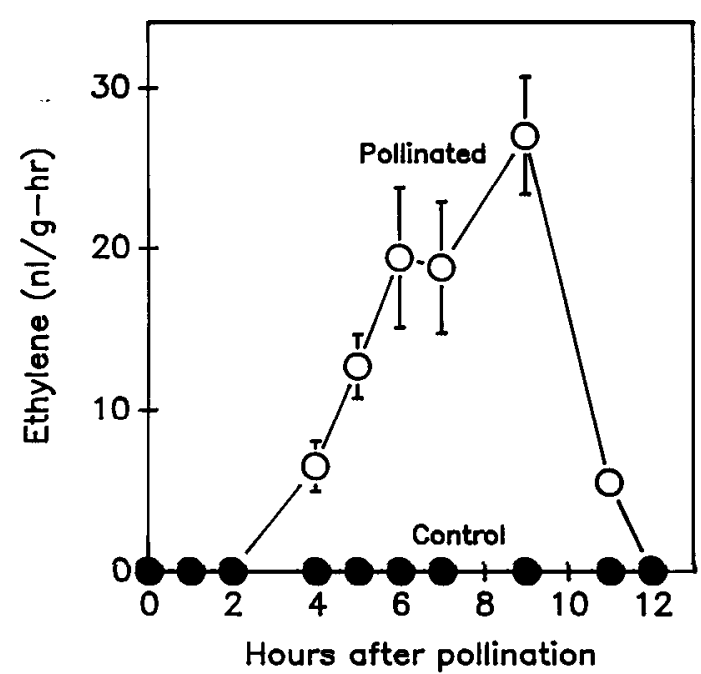

Fig. 1. Rate of ethylene evolution after pollination of Triteleia laxa flowers. at anthesis showed constant ovary growth (Fig. 2C). Treatment with $\mathrm{C}_{2} \mathrm{H}_{4}\left(1 \mu \mathrm{l} \cdot\right.$ liter $\left.^{-1}\right)$ enhanced enlargement of ovaries of flowers from all stages (Fig. 2).

To examine the role of petals and carbohydrates in ovary growth, flowers detached at various stages of development (with or without petals) were placed in solutions containing $0 \%$ or $2 \%$ sucrose and $200 \mathrm{mg}$ HQC/liter. Ovary growth was always promoted by sucrose. In flowers harvested as buds, petal removal enhanced ovary growth. In flowers harvested at anthesis,

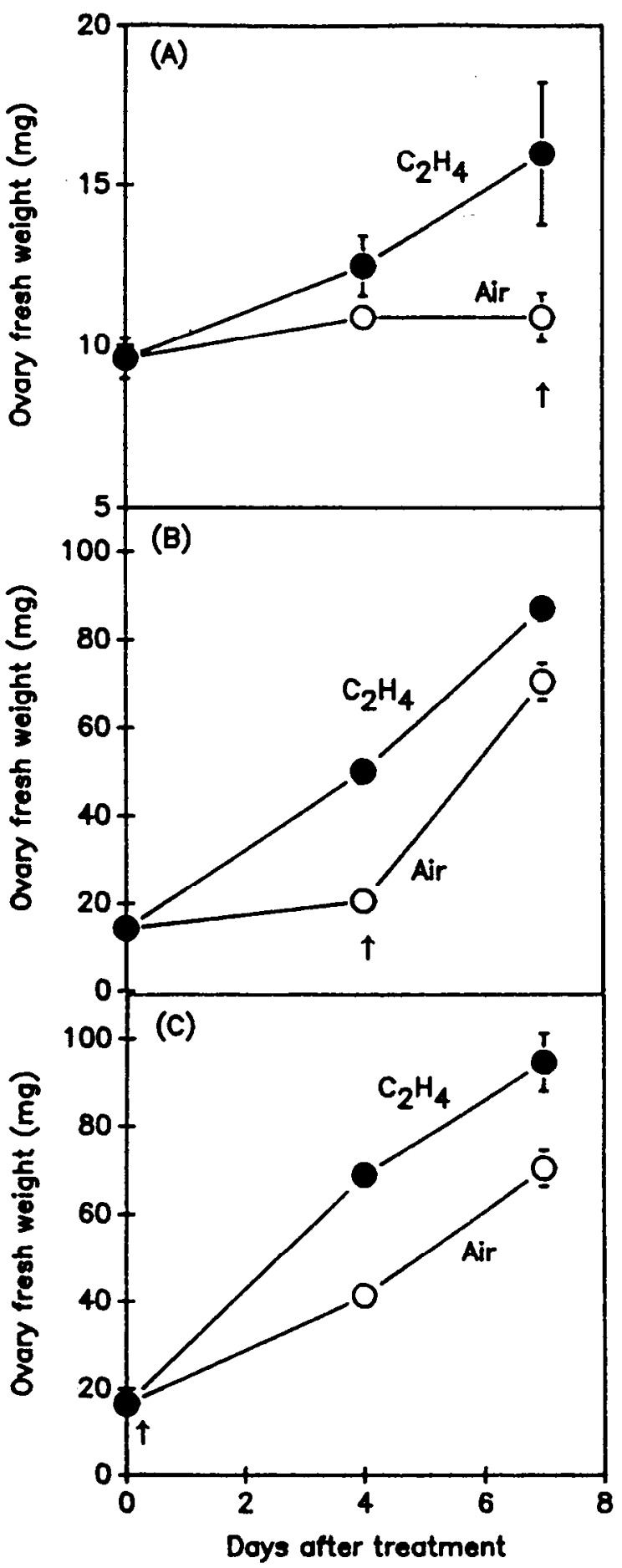

Fig. 2. Effects of continuous ethylene treatment $\left(1 \mu \mathrm{l} \cdot\right.$ liter $\left.^{-1}\right)$ on ovary growth of flowers of Triteleia laxa: (A) 1-cm buds, (B) buds showing color, and (C) flowers at anthesis. Arrows indicate time of anthesis. Standard error bars smaller than the symbols are not shown. 
after petals were fully expanded, petal removal retarded ovary growth (Table 2).

Ethylene treatment of intact flowers harvested at anthesis almost doubled ovary growth (Table 3). Removal of the petals eliminated the $\mathrm{C}_{2} \mathrm{H}_{4}$ response. STS partially counteracted the promotive effect of exogenous $\mathrm{C}_{2} \mathrm{H}_{4}$ on ovary growth "in intact flowers.

Pollination. Field observations indicated rapid ovary growth following insect pollination. In initial experiments to test the effect of pollination on $\mathrm{C}_{2} \mathrm{H}_{4}$ production and flower life, brodiaea flowers were pollinated at anthesis. There was no resulting production of $\mathrm{C}_{2} \mathrm{H}_{4}$ or any acceleration of ovary growth, and it seemed possible that brodiaea flowers were dichogamous. Pollination of flowers at different stages of development demonstrated that brodiaea flowers are protandrous. Pollination of flowers with senescing petals caused increased $\mathrm{C}_{2} \mathrm{H}_{4}$ production and ovary growth. Ethylene evolution started to increase $4 \mathrm{hr}$ after pollination, reaching a peak of $24 \mathrm{nI} \cdot \mathrm{g}^{-1} \cdot \mathrm{hr}^{-1} 5 \mathrm{hr}$ later (Fig. 1). No measurable $\mathrm{C}_{2} \mathrm{H}_{4}$ was produced by nonpollinated flowers or pollinated flowers whose stigma was pretreated with $1 \mathrm{mM}$ AOA. Application of $2 \mathrm{mM}$ STS to the stigma stimulated $\mathrm{C}_{2} \mathrm{H}_{4}$ evolution (data not shown).

Ultrastructure of the developing stigma. At anthesis, the papillae on top of the stigma were tightly packed together (Fig. $3 a)$. By 5 to 6 days after anthesis, when petals had started to senesce and the stigma was receptive, the papillae had elongated and separated (Fig. 3b), and pollen grains lodged between the

Table 2. Effects of petal removal on growth of ovaries in detached individual flower buds of Triteleia laxa harvested at various stages of development and placed in opening solutions containing either $0 \%$ or $2 \%$ sucrose with $200 \mathrm{mg}$ HQC/liter. Ovary weights of all flower buds were determined when petals of open flowers senesced. Data are the means of 10 flowers.

\begin{tabular}{|c|c|c|c|c|c|c|}
\hline \multirow{3}{*}{0} & \multicolumn{6}{|c|}{ Stage of flower } \\
\hline & \multicolumn{2}{|c|}{$1-\mathrm{cm}$ buds } & \multicolumn{2}{|c|}{$\begin{array}{l}\text { Buds showing } \\
\text { color }\end{array}$} & \multicolumn{2}{|c|}{ Open } \\
\hline & & $\cdot$ & \multicolumn{2}{|c|}{ Petals } & & \\
\hline Ovary wt (mg) ${ }^{x}$ & + & - & + & - & + & - \\
\hline $\begin{array}{l}\text { Initial } \\
\text { Final }\end{array}$ & $9.6 \mathrm{a}$ & $9.6 \mathrm{a}$ & $14.2 \mathrm{a}$ & $14.2 \mathrm{a}$ & $16.4 \mathrm{a}$ & $16.4 \mathrm{a}$ \\
\hline $\begin{array}{l}\text { (0\% sucrose) } \\
\text { Final }\end{array}$ & $10.5 \mathrm{a}$ & $15.7 \mathrm{~b}$ & $16.9 \mathrm{a}$ & $29.0 \mathrm{~b}$ & $47.3 c$ & $25.1 \mathrm{~b}$ \\
\hline (2\% sucrose) & $16.8 \mathrm{~b}$ & $22.3 c$ & $31.2 \mathrm{~b}$ & $40.1 \mathrm{c}$ & $60.8 \mathrm{~d}$ & $50.7 \mathrm{c}$ \\
\hline
\end{tabular}

${ }^{\mathrm{z}}$ Means separated within columns by Duncan's multiple range test $(P$ $=0.05)$.

Table 3. The effect of petal removal, exposure to ethylene $\left(1 \mu \mathrm{l} \cdot \mathrm{liter}^{-1}\right)$, and pretreatment with STS $(4 \mathrm{mM}, 30$ rein) on ovary growth of Triteleia laxa. Individual flowers harvested at anthesis were placed in $2 \%$ sucrose + HQC. Ovary weights were determined when petals of the control flowers started to wilt. Data are the means of five flowers.

\begin{tabular}{|c|c|c|c|}
\hline \multicolumn{2}{|c|}{ Treatment } & \multicolumn{2}{|c|}{ Ovary fresh wt $(\mathrm{mg})^{z}$} \\
\hline Ethylene & STS & With petals & Petals removed \\
\hline- & - & $36.8 \mathrm{~b}$ & $24.2 \mathrm{a}$ \\
\hline+ & - & $67.8 \mathrm{~d}$ & $27.6 \mathrm{a}$ \\
\hline - & + & $28.3 \mathrm{a}$ & $25.5 \mathrm{a}$ \\
\hline+ & + & $47.6 \mathrm{c}$ & $24.2 \mathrm{a}$ \\
\hline
\end{tabular}

${ }^{7}$ Means separated within columns by Duncan's multiple range test $(P$ $=0.05$ ). papillae (Fig. 3c). The pollen grains had already germinated 12 hr after pollen application (Fig. 3d).

\section{Discussion}

In various flowers, pollination results in accelerated wilting (Nichols et al., 1983; Whitehead et al., 1984), associated with enhanced ethylene production. 'Queen Fabiola' brodiaea flowers are interesting examples of this trait, differing from the majority of species studied so far in that normal senescence does not involve production of ethylene. Their behavior resembles that of cyclamen (Halevy et al., 1984), which produce ethylene only after pollination. Unlike cyclamen, however, unpollinated brodiaea flowers are sensitive to ethylene.

Another curious feature of the brodiaea flower is the very late stage at which the stigmas become receptive (when the petals start to wilt). Only at this stage does pollination elicit ethylene production and senescence. The receptivity of the stigmas is associated with opening of the papillae on the stigmatic surface (Fig. 3). Whether the earlier lack of receptivity is simply a mechanical restriction to pollen germination is not yet known.

In their response to $\mathrm{C}_{2} \mathrm{H}_{4}$, brodiaea flowers behave somewhat similarly to some cultivars of roses (Reid et al., 1989). Although they do not produce measurable $\mathrm{C}_{2} \mathrm{H}_{4}$ during their entire life, both open flowers and flower buds are very sensitive to $\mathrm{C}_{2} \mathrm{H}_{4}$. Continuous exposure to $0.03 \mu \mathrm{C}_{2} \mathrm{H}_{4} /$ liter or a 2-day treatment with $1 \mu \mathrm{l} \cdot$ liter $^{-1}$ irreversibly prevented bud opening and induced rapid senescence of open flowers (Table 1). Silver thiosulfate, which blocks $\mathrm{C}_{2} \mathrm{H}_{4}$ action and extends flower longevity in many flowers, also inhibited the effects of $\mathrm{C}_{2} \mathrm{H}_{4}$ on brodiaea flowers (Table 1). Ethylene concentrations higher than $0.03 \mu l \cdot$ liter $^{-1}$ are common in the atmosphere of various locations where flowers are held (Reid et al., 1989); for longest vase life under commercial conditions, brodiaea flowers should therefore be treated with STS.

There have been many studies on the physiology of senescing carnation flowers and there has been some controversy as to the role of carbohydrate movement between the senescing petals and the developing ovaries (Cook and Van Staden, 1983; Mor et al., 1980; Nichols, 1971). Carbohydrates are obviously required for ovary development and it has been suggested that the ovary of $\mathrm{C}_{2} \mathrm{H}_{4}$-treated carnations grows at the expense of carbohydrate reserves in the wilting petals (Nichols, 1971). Others showed that removal of the petals had no effect on ovary growth, and concluded that the growth of the ovary was not dependent on reallocation of carbohydrate materials from the petals (Mor et al., 1980). Still others showed that application of ethrel accelerated petal senescence and enhanced ovary growth. Ovaries from carnation flowers with petals removed weighed less than those from intact flowers, suggesting that metabolizes move from the senescing petals to the developing ovary (Cook and Van Staden, 1983).

T. laxa flowers provide a good system to study the role of petals in ovary growth because their single and easily detached corolla is a more uniform tissue than the petals of carnations. The data obtained from brodiaea indicate time-dependent changes in competition among the floral organs for carbohydrate. In young brodiaea flowers, removal of the petals increased ovary growth, indicating that the growing petals were the strongest sink for carbohydrate from the stem (Table 2). These data are similar to those obtained from carnation flowers pretreated with chemicals that delay flower senescence, such as STS (Cook and Van Staden, 1983; Mor et al., 1980) and ethanol (Cook and Van Staden, 1983). Addition of sucrose to the vase solution 

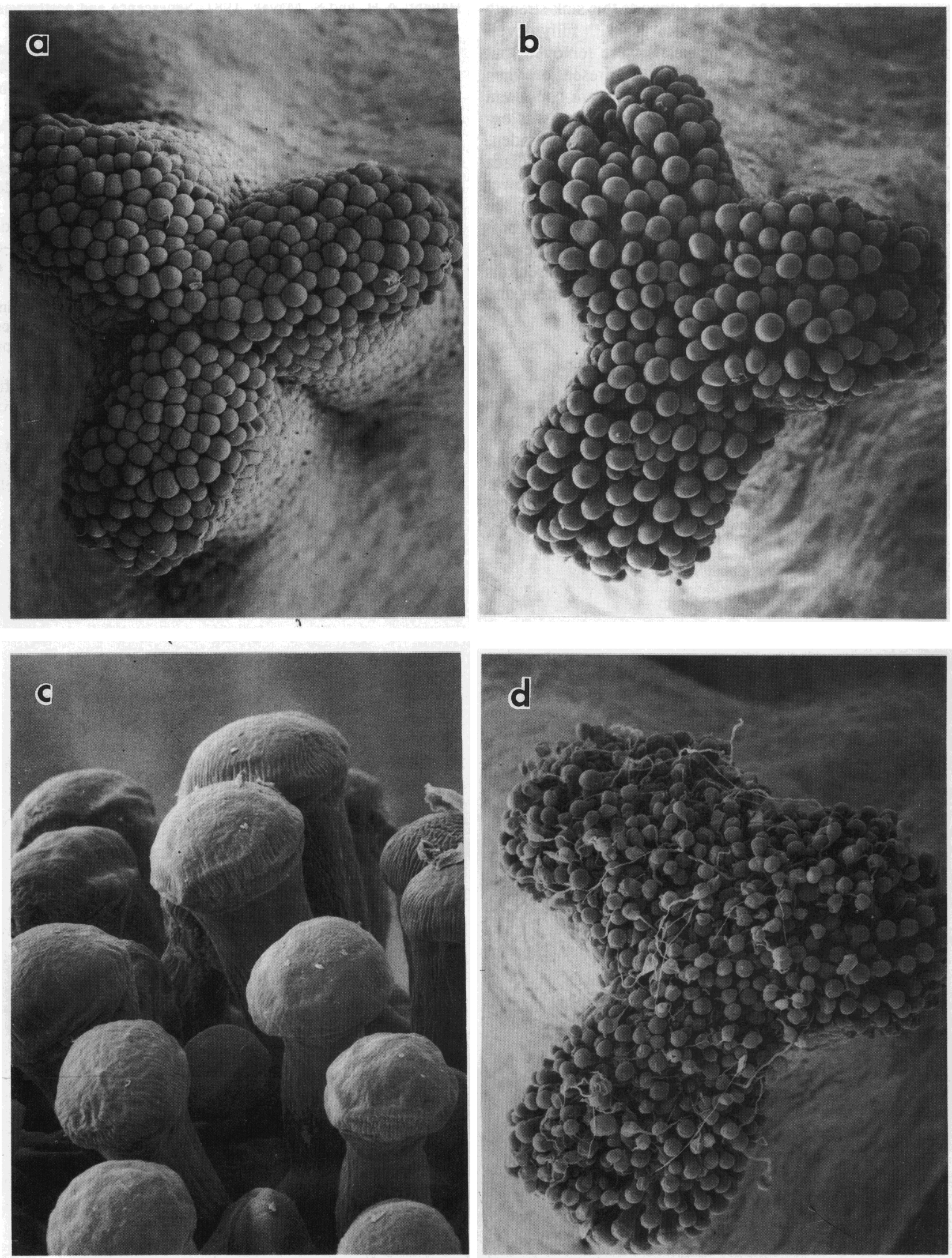

Fig. 3. Scanning electron micrograph of a Triteleia laxa (a) nondeceptive stigma (at anthesis), (b) receptive stigma (petals started to senesce), (c) receptive stigma with pollen grains lodged between the stigmatic papillae, (d) stigmatic surface with pollen tubes fully grown 12 hr after pollination. 
increased growth of both organs, which supports this sink-strength hypothesis. In contrast, the ovaries of flowers with fully developed petals grew only slightly if the petals were removed, but increased by 3- to 4-fold when the petals were present or when the stems were provided with sugar. These data are consistent with those from carnation flowers, whose senescence was enhanced by pretreatment with ethephon (Cook and Van Staden, 1983). The changed response to petal removal as the brodiaea flower ages indicates that the ovary in the aging brodiaea flower becomes a very strong sink for carbohydrate from either the stem or the senescing petals. These results suggest that in brodiaeas and carnations (Cook and Van Staden, 1983; Mor et al., 1980) ovary growth is a function of the relative sink strengths of the ovaries and petals for carbohydrate from the stem and the vase solution.

\section{Literature Cited}

Cook, E.L. and J. Van Staden. 1983. Senescence of cut carnation flowers: Ovary development and $\mathrm{CO}_{2}$ fixation. Plant Growth Reg. $1: 221-232$.

Gob, C. J., A.H. Halevy, R. Engel, and A.M. Kofranek. 1985. Ethylene evolution and sensitivity in cut orchid flowers. Scientia Hort. 25:57-67.
Halevy, A.H. and S. Mayak. 1981. Senescence and postharvest physiology of cut flowers, part 2. Hort. Rev. 3:59-143.

Halevy, A. H., H.C. Kohl, and A.M. Kofranek. 1984. Senescence and postharvest handling of cyclamen flowers. HortScience 19:848-850.

Mor, Y., M.S. Reid, and A.M. Kofranek. 1980. Role of the ovary in carnation senescence. Scientia Hort. 13:377-383.

Nichols, R. 1968. The response of carnations (Dianthus catyophyllus ). J. Hort. Sci. 43:335-349.

Nichols, R. 1971. Induction of flower senescence and gynoecium development in the carnation (Dianthus caryophyllus) by ethylene and 2-chloroethylphosphonic acid. J. Hort. Sci. 46:323-332.

Nichols, R., G. Buffler, Y. Mor, D.W. Fujino, and M.S. Reid. 1983. Changes in ethylene production and 1-aminocyclopropane-1 -carboxylic acid content of pollinated carnation flowers. J. Plant Growth Reg. 2:1-8.

Reid, M. S., J.L. Paul, M.B. Farhoomand, A.M. Kofranek, and G.L. Staby. 1980. Pulse treatments with the silver thiosulfate complex extend the vase-life of cut carnations. J. Amer. Soc. Hort. Sci. 105:25-27.

Reid, M. S., R.Y. Evans, L. Dodge, and Y. Mor. 1989. Effects of ethylene and silver thiosulfate complex on the opening of cut rose flowers. J. Amer. Soc. Hort. Sci. 114:436-440.

Whitehead, C. S., A.H. Halevy, and M.S. Reid. 1984. Roles of ethylene and 1-aminocyclopropane-1 -carboxylic acid in pollination and wound-induced senescence of Petunia hybrida flowers. Physiol. Plant. 61:643-648. 